\section{Generativity and balance in leadership}

\section{Chiara Ghislieri and Paola Gatti}

University of Torino, Italy
Leadership

8(3) 257-275

(C) The Author(s) 2012

Reprints and permissions: sagepub.co.uk/journalsPermissions.nav DOI: $10.1177 / 1742715012441177$

lea.sagepub.com

(SAGE

\begin{abstract}
The ability to transform follocwers into new leaders is an important task for leadership, as it guarantees organizational continuity and generativity. At the same time, however, it is a challenge that too often goes unanswered. In particular, research data emphasize that intergenerational transfer is highly critical in Italy: the number of elderly entrepreneurs, executives and top managers, for example, has increased significantly in recent years. This article presents a theoretical reflection on this issue, and has four main goals: to introduce the Italian leadership situation; to describe and understand the 'dark side of leadership' with particular attention to narcissism in leadership; to identify the main elements which can promote 'generative leadership' in organizational contexts (i.e. in this paper, a leadership based on the idea of generativity developed by Erik Erikson in 1968), highlighting the ability to achieve balance in leadership as a core aspect; and to provide suggestions about leadership training and development programmes, with a special focus on mentoring and coaching.
\end{abstract}

\title{
Keywords
}

leadership, narcissism, generativity, succession

\section{Introduction}

Since the beginning of the transformational leadership model (with the seminal work of James MacGregor Burns), researchers have viewed one particular capacity as the distinctive feature of good leadership: transforming followers into future leaders. Succession to a leadership role is thus a crucial element in organizational studies.

The ability to transform our followers into new leaders is a critical task for leadership and guarantees organizational continuity. At the same time, however, it is a challenge that leaders in Italy (and elsewhere) are all too often unable to meet. In particular, research 
emphasizes that intergenerational transfer is highly critical in Italy (Carboni et al., 2009): the data indicate, for example, that the number of elderly entrepreneurs, executives and top managers has increased significantly in recent years. This difficulty and its critical consequences (power vacuum and poorer and poorer managerial classes) stimulate theoretical reflection on the link between leadership and power.

The article presents a theoretical reflection on this issue, and has four main goals: 1) to introduce the Italian leadership situation; 2) to describe and understand some aspects of the 'dark side of leadership'; 3) to identify the generative leadership in organizational contexts; 4) to provide suggestions about leadership training and development programmes.

Regarding the first goal, the paper will present several of the reasons that can help clarify the current significance of the problem of succession to leadership and the importance of supporting generativity in leadership in Italy.

Regarding the second goal, the key aspects of the 'dark side of leadership' and its use of power are discussed, with particular attention to narcissism in leadership (Higgs, 2009; Kets de Vries and Miller, 1997). This reflection is rooted in psychodynamic literature, which can provide insight into these leadership dynamics.

As regards the third aim, the paper will investigate how, from a psychodynamic standpoint and drawing on the ideas of Erik Erikson (1968), generativity in leadership entails an ultimate goal of generating new leadership (or, as work in transformational leadership has indicated, of turning followers into leaders). One of the most important factors in this connection is being capable of combining other leadership skills with the ability to achieve balance. Being able to act with balance can be considered the 'measure' of leadership (Kets de Vries, 2007). This variable can guarantee a mindful, open, careful and focused relationship with others, promoting a detoxified organizational culture in which a good quality of life is sustainable (Allcorn and Diamond, 1997; Frost, 2004). Consequently, achieving balance in visioning and challenging, sharing and caring is a fundamental resource for generative leadership.

Lastly, the implications for leadership training and development are discussed. Among training opportunities, mentoring and coaching are identified as useful ways of trying to bring the dark side of leadership back into the light.

\section{Lack of generativity: An Italian problem?}

Generativity in leadership and the succession to leadership is a highly topical problem in a number of areas of national importance to Italy, from politics to business. The average age of Italy's political leaders is significantly higher than that of their counterparts abroad, while a number of major Italian corporations are (or until recently were) headed by entrepreneurs of unquestioned ability and value, but who are by no means young.

The problem of succession is thus an important one in Italy, especially for family-owned businesses. As Nadio Delai (2009) has written in a recent paper scrutinizing the Italian scene, business continuity is a central issue because a significant number of enterprises are now having to face the first, if not the second or third, generational transition. Just how important the question of Italy's 'aging' businesses is for the country can be seen from the European Commission Communication entitled Transfer of Businesses - Continuity through a new beginning, dated 14 March 2006 (European Commission, 2006b). The Commission notes that in Italy a transfer potential of $40 \%$ of all companies has been forecasted for the next decade. 
In addition, the problem of aging businesses is compounded by that of aging businessmen. According to the May 2006 report of the European Commission expert group, around $42 \%$ of Italy's entrepreneurs are over 50 years old, and around 7.5\% are over 70 (European Commission, 2006a). Nor is this all: Delai (2009) points out that the number of people in positions of responsibility who were 70 years old or older rose significantly between 2003 and 2007.

The fact that this is now a pressing issue for Italy also emerges from the findings of a study of business continuity conducted in 2009 by LUISS, and commissioned by the Young Entrepreneurs Group of Confindustria, the Federation of Italian Industries, and by the Unicredit Group (Carboni et al., 2009). For this survey, an ad hoc questionnaire was administered to 435 young business people and 113 senior business people from various parts of Italy. Many respondents from both groups indicated that generation change is a problem affecting their own company now, or a problem which it will have to deal with in the near future. As for the perceived difficulties in negotiating the passage to the next generation, the percentage of respondents who expect the change to be problematic is not particularly high (14.8\% of the young business people and $12.8 \%$ of the senior business people). However, a much higher percentage $(61.3 \%$ of the younger group and $58.1 \%$ of their elders) forecast that the transition will be hard, though not impossibly so. On the whole, then, there is a rather widespread and understandable sense of worry about the question and how it is to be faced.

This concern is shared by the European community, which has been aware of the problem for some time. As early as 1994, the European Commission identified several fundamental lines of action for business transfers, subsequently publishing a Recommendation for Member States on the transfer of small- and medium-sized enterprises (European Commission, 1994). The Commission recently announced that the problem has to some extent been addressed, but has not been solved. Indeed, one of the paragraphs of the Communication of 14 March 2006 is headed 'Progress not sufficient', and notes that measures are in place only in about $55 \%$ of the areas of the 1994 recommendations. Initiatives designed to address this crucial problem in the EU's Member States are thus in order, such as the recent project entitled A Helping Hand for SMEs - Mentoring Business Transfer (European Commission, 2009). Coordinated by Eurochambres, the project aimed to provide mentoring support to 1000 buyers of businesses with fewer than 50 employees in 18 European countries including Italy, each for a 10-day period.

While the countries of the European Union thus share many of the same worries, Italy's family businesses would appear to have a number of distinctive traits that affect their prospects of surviving generation change (Passeri, 2007). One significant aspect is poor succession planning: in Italy 'the processes of generational change often take place without planning' (Passeri, 2007: 12). This was pointed out as long ago as 1997, when a study by Corbetta and colleagues (see Gambel, 2004) provided supporting data from a comparison between Italy and the United States. It was found, for example, that only 7\% of Italian entrepreneurs stated that they had written rules for succession planning, as against $44 \%$ of US entrepreneurs. Only $11 \%$ had set themselves an age limit averaging around 65 years, whereas approximately $40 \%$ of US entrepreneurs intended to retire at 60 .

Last, though not in order of importance, is the aspect of culture and its influence on business transfers. Cultural studies - most notably the GLOBE studies (House et al., 2004) in the specific area of culture and leadership - can thus provide a wealth of insight. Many Italian scholars are also well aware of these cultural influences on leadership and 
business transfer, focusing on them to varying extents. While the central role of the family in businesses is not limited to Italy alone, the 'family's attachment to the business in Italy appears to stem essentially from reasons of a cultural nature' (Passeri, 2007: 12). It is important to recognize that 'in our country, the family cell fulfils a special function' in firms (Marturano, 2009: 96), and that cultural values encourage the maintenance of firms within the family (Cucculelli and Micucci, 2008) - a function that is special, and encouraged, but not without risk. The first risk is to the family-owned business's bottom line. A recent survey of a sample of Italian family firms in the manufacturing sector located in four regions of the country found a decrease in the post-succession performance that is larger for the heirmanaged firms than for the companies managed by unrelated CEOs (Cucculelli and Micucci, 2008). The second risk is that the complex process of building credibility and legitimacy, which heirs often find themselves obliged to face, may make for a slower and more taxing succession (Gambel, 2004). One cultural element, which could add to the obstacles encountered along this road to legitimacy, consists of Italy's widespread perception of the predominance of leaders interested in protecting their own interests or at most those of their own group (Rapporto Luiss, 2008). This is also reinforced by the findings of the GLOBE studies, which indicate that the view of leadership typical of Latin Europe (of which Italy is a part), as opposed to the other regional-cultural clusters investigated in these studies, is that of a leadership which is highly charismatic rather than humane-oriented, and is thus not seen as being particularly supportive, compassionate and sensitive to other people (Northouse, 2010); as a result, one might add, it is far from 'follower-oriented', making it feared and viewed with suspicion during transition. Lastly, the risk posed by the link between culture and leadership must also be borne in mind: as noted by Dorfman (2004), the cultural differences that may exist even between different areas of the same country can be quite pronounced, and we ignore them at our peril.

While the following pages will concentrate on the psychodynamic literature dealing with the topic, it should be noted that there is an extensive tradition of work centring on the cultural aspect, in addition to the GLOBE studies mentioned here.

The data presented here apply to the question of family entrepreneurship and business transfer. Leadership and entrepreneurship, however, are closely linked, and although the studies addressing each have followed parallel paths, we can see a number of intersections and mutual lessons (Cogliser and Brigham, 2004), common trends and common threads (Vecchio, 2003). The theme of succession is one of these common elements, a leadership problem that is more visible and has distinctive features in family businesses (Cucculelli and Micucci, 2008; Kets de Vries, 1995; Pardo-del-Val, 2009).

\section{A psychodynamic perspective: The bright and the dark side of leadership}

The theme of succession, though often cited as central in the leadership literature, has attracted few attempts to understand its dynamic, and in particular the leader-follower dynamics in depth. As the foregoing brief description of the Italian situation indicates, however, succession is often a critical aspect. This paragraph will introduce the topic of succession, showing how its critical nature (and, more generally, that of the leader-follower relationship) has received little attention in the majority of leadership studies, especially those centring on the heroic approach. We will thus introduce the work that has been done on the dark side of leadership and, in particular, the psychodynamic studies that 
have focused on power (Kets de Vries, 1993), personality types (Stech, 2010) and, above all, on narcissism (Kets de Vries, 1995; Maccoby, 2000).

As regards succession, from the time the idea of transformational leadership was first introduced (Burns, 1978), turning followers into new leaders has been seen as the fundamental task of change. Creating new leadership is the heart of transformational leadership, an idea that has been taken up by authentic leadership theory (Avolio and Gardner, 2005). However, the problems and difficulties it involves have often not been acknowledged, nor have the dysfunctional dynamics been analysed. The leadership literature has chiefly concentrated on the characteristics of 'good' leadership and especially on its heroic connotations, despite the many criticisms levelled against this approach (Higgs, 2009): many see the heroic model as providing little more than a discourse relating to a few major US CEOs (Alimo-Metcalfe, 1995). For its part, the transformational model retains the heroic approach's focus on vision, the charismatic side of communication that convinces, as opposed to communication that gets other people involved.

The influence of the heroic model, despite its limited ability to understand and explain leadership, has led to a view of the topic that is based largely on the leader's profile and the dependence of the followers, rather than on their potential for growth. This has hampered efforts to understand the more deep-seated dynamics of leadership (Higgs, 2003; McGill and Slocum, 1998).

Only recently has the work of a few authors (Higgs, 2009) brought about a shift in attention, which no longer concentrates entirely on good leadership and its more or less linear effectiveness, but also extends to dysfunctional dispositions in the workplace (Khoo and Burch, 2008), the dark side of leadership (Conger, 1990). In reality, this interest in the dark side dates back to the early 1980s, when early work on leadership derailment or failure (McCall and Lombardo, 1983) identified its causes as resulting from a combination of factors where the leader's dysfunctional tendencies appeared to be more important than deficiencies in specific skills.

However, a number of years were to pass before the topic of 'bad' leadership reappeared in the literature (Benson and Hogan, 2008). The other face of leadership has been given a number of different names in addition to leadership derailment (McCall and Lombardo, 1983): toxic leadership (Lipman-Blumen, 2005), negative or evil or 'dark side' leadership (Conger, 1990), abusive or destructive leadership (Higgs, 2009). 'Bad leadership' corresponds to a general worsening in performance (Benson and Hogan, 2008; Chatterjee and Hambrick, 2007): while it may possibly result in short-term success, in the long term it will lead to a significant drop in performance and adverse effects on psychological well-being, job satisfaction and affective commitment. In some cases, performance may continue to be good 'in the leader's presence' but his or her absence will inevitably result in failure.

Recently, Aasland and colleagues (2010) found that destructive leadership (laissez-faire, supportive-disloyal, derailed or tyrannical) is anything but rare in organizational life, not least because destructive and constructive behaviours often alternate and intertwine.

When the prevailing tone of leadership is 'negative' (Conger, 1990), it thus fails to guide change: the leader is inclined to pursue personal goals rather than to promote occasions of change that can benefit others and the organization. Where leadership is self-centred, though still charismatic and inspiring involvement, it ends in failure - and there can be no doubt that it will fail in its main task of generating leadership (Quaglino, 2004). Succession is given no thought, and no preparations are made for it. 
The various forms that negative leadership can assume all spring from core considerations of power; leadership is the exercise of power, and the quality and consequences of leadership depend on the ability to exercise power (Kets de Vries, 1993). One of the aspects that arise here is abuse of power, in other words using power to achieve personal gain, often through unethical or even illegal conduct, to reinforce self-image to the detriment of others, to inflict damage and gain standing, recognition and (in a vicious circle) more power (Higgs, 2009).

But what are the causes, the determinants of these dysfunctional forms of leadership? To date, few studies have addressed the question. Hogan, Curphy and Hogan (1994) proposed that bad leadership depends on extreme levels of certain personality traits such as ambition (which in extreme becomes constant competition) or, conversely, agreeableness, which can result in inappropriate conflict-avoiding behaviour when carried to the limits.

However, the author who made the most thorough attempt to understand the dynamics underlying leadership behaviour was Kets de Vries (1993), who suggested that bad leadership resulted from an unresolved sense of self, an unrealistic idea of one's power and the fear of losing it. This author sees organizational life as a field of power and each individual's power orientation as being deeply rooted in the personality structure, as it originates in the early relationships with parental figures (Kets de Vries, 1980), and is then consolidated and reactivated in all relational situations that involve exercising power. Developing a sense of self, self-confidence, recognition by others and distinguishing between internal and external sources of gratification all contribute to forming power orientation.

Alongside the theme of power, the psychodynamic approach indicates that narcissism, an attribute of many powerful leaders (Rosenthal and Pittinsky, 2006), is associated with a limited ability to generate succession. Narcissism is a personality disposition encompassing grandiosity, arrogance, self-absorption, entitlement, weak self-esteem and sometimes hostility. Kets de Vries (1995) made a fundamental contribution in recognizing narcissism as an infantile element of leadership. Individuals affected by narcissism are thus characterized by a sense of grandeur and omnipotence, together with a desire for admiration and prestige, and are most likely to rise to positions of leadership, because these individuals are recognized as leaders by their followers and by everyone who has working relationships with them (Kets de Vries, 1995). Whereas constructive narcissists have greater selfconfidence and ability to cope with frustration (calling to mind Maccoby's productive narcissist, 2000), and are thus better able to keep up a relationship, the reactive narcissist and the self-deceptive narcissist can show more problematic behaviour in dealing with their followers.

Reactive narcissists lack a stable sense of self-esteem, which they compensate for with forms of exhibitionism and a pronounced tendency towards grandiosity. In terms of generativity, this can translate into a desire to mould co-workers rather than helping them grow, sparking feelings of frustration (Kets de Vries, 1995).

By contrast, self-deceptive narcissists have grown up with an illusion of perfection, leading to deep-seated insecurity in their grasp on reality. The image of perfection is thus forcedly safeguarded through mechanisms of illusion that entail a distorted relationship with reality, and a refusal to acknowledge problems and mistakes. Clearly, this type of narcissism involves a lack of generative orientation (Quaglino, 2004). This also depends on the fact that narcissistic leaders often spend more energy promoting their own image than on promoting their colleagues' development (Conger, 1990; Resick et al., 2009).

The grandiosity and positive self-presentation that make narcissists more inclined to aspire to and obtain leadership positions are the same traits that in the long run will 
cause their leadership to be seen as poor or ineffective (Rosenthal and Pittinsky, 2006). Narcissistic leaders' excessive self-centredness may be attractive at the outset, but over time will become a sore point in relationships with associates who are not supported in their growth. At the same time, grandiosity, often accompanied by denial of different points of view, problems or unwelcome information, can bring immediate recognition that does not necessarily carry over into lasting accomplishments.

Kets de Vries also contributes to an understanding of failing successions in his 1993 book, in which he notes that times of 'loss of power' can be associated with emotional turmoil: if obtaining power can compensate for the midlife crisis, losing it means having to contemplate one's own 'non-existence', especially in cases where identifying with the role of leader is extremely important to personal identity.

This is all the more true for family-controlled firms (Kets de Vries, 1995), which have their own specific aspects and distinctive features and whose approach to succession has been investigated by a number of authors (Pardo-del-Val, 2009). In these firms, the idea of succession unleashes intense emotivity, at times with such a high degree of conflict that it is often denied, with no advance planning or preparation building up to it. And finally, although our focus in these pages is on the leader, it is obvious that the followers also have a decisive role (Clements and Washbush, 1999; Kets de Vries, 2001) through their willingness to 'go with the flow' via collusion mechanisms.

From a psychodynamic standpoint, succession is difficult for reasons that are deeply rooted in individual histories and carry over into organizational life. What we have seen so far, then, is that is precisely those individuals who are regarded as leaders who could have difficulty in managing succession, and can thus show very little generativity.

\section{Generativity and balance}

Several authors have recently used the expression generative leadership (Surie and Hazy, 2006), with reference to theories about complex adaptive systems, to describe a leadership capable of creating the conditions for autonomy and integration, facilitating the team's performance, and thus giving employees the role of integrated autonomous co-workers (Åteg et al., 2009).

Our intention in this paper is to direct attention to the psychodynamic meaning of the term generativity, drawing on the idea of Erik Erikson (1968), for whom it is a concern for establishing and guiding the next generation, calling for care and oriented towards making others grow. From this standpoint, the crucial task of generative leadership goes well beyond developing a new vision or creating new businesses. For this type of leadership, what is most crucial is transforming followers into future leaders: generating leadership in others, sharing and extending power.

Many of the factors that are important in achieving this goal have been identified in the literature: facilitating interactions, promoting dialogue capacity, encouraging clearness and transparency. One element, however, cuts across all of these skills, an element we can define as a capacity for 'achieving balance' which means: indicating the way ahead without keeping too tight a rein or leaving followers entirely to their own devices; being mindful of the risks of abandonment on the one hand and obduracy on the other; harmonizing presence and absence, custom and innovation, renewal and routine; modulating action and thought, imagination and reality, acceptance of risk and vigilance; avoiding the opposite extremes of giving way to an excessive, unthinking or ill-managed affectivity, and of denying 
one's sentiments; reflecting on the discordances that arise between what one feels and what one shows (Quaglino, 2009).

For leadership to be generative, there must thus be a balance in relationships with followers that supports learning and change. A number of investigations, both psychodynamic and otherwise, have made some reference to this idea of balance. In dealing with followers (as well as with colleagues), achieving balance means avoiding the extremes of insensitivity to other people's emotions and over-involvement (Frost, 2004). It means sharing information and knowledge generously, but not as a means of moulding co-workers. Balanced leadership demands awareness, consciousness (Daft and Lengel, 1998). Thus, the degree of balance achieved by the leader can help in establishing a mindful relationship, or in other words one capable of being attentive to what the other person - the follower - brings to the relationship and the nature of his or her engagement rather than imposing oneself as a preconstituted style (Kellerman, 2007).

'Balanced' leaders, moreover, are those who, recognizing that they are incomplete (Ancona et al., 2007), are willing to achieve completion in the relationship with the follower, leaving room for sharing, an area for full exchange that makes it possible for power to be effectively shared. This fullness entails accepting difficulties, creating a climate which is not positive at all costs (as is typical of self-deceptive narcissism), but able to allow disagreement to be expressed and errors and problems to be recognized; this can help boost colleagues' participation by making them more confident and free to express themselves honestly. To accomplish this, it is essential to overcome the fear of 'losing popularity', even before the fear of 'losing power'.

In managing change, balance is also the ability to calibrate acceptance of the risk associated with the transformation and its challenge, and constant watchfulness (Hirschhorn, 1998). Generative leaders are close to the profile of the builder (Kets de Vries, 2007): they dream of creating something and have the talent and determination to do so concretely. They are energetic and balanced in the long term, prepared to take risks but also to gauge the distance that separates them from their goal, as they are well aware of the differences between dream and reality. They keep careful tabs on signals from inside and outside the organization, and are willing to change their ground if necessary.

This would appear to be crucial in the current age of uncertainty, when the idea of balance can also be interpreted with an eye to the concept of negative capability (Simpson et al., 2002). Negative capability is a term coined by Keats in 1817 (see Keats, 1984) to express the ability to remain content with half knowledge: it is the capacity to tolerate anxiety and fear, remain in uncertainty in order to allow new thoughts and perceptions to emerge. Negative capability makes it possible to create mental and emotional room for constructive, problemsolving thought.

Accepting the challenge of balance, then, means promoting an organizational culture where anxieties are contained, fears are consciously thought out, participation in organizational life is full and legitimate, relationships are detoxified and the quality of life is sustainable (Allcorn and Diamond, 1997; Frost, 2004; Frost and Robinson, 1999). This culture is that of free expression, of conflict as an occasion for negotiation, of experience as a source of learning.

\section{Developing generative leadership}

The leadership described above thus plays a decisive role for organizations. However, as the literature on the dark side and on narcissism shows, expressing this leadership in 
organizational life is by no means easy. Taking a leadership role calls for a commitment to a continual process of learning and self-development (Hill, 2007).

If the task of taking leadership is complex, it is no less difficult to design effective training programmes to develop it. The limits that programmes in this field can come up against are legion, and are only partially justified by the fact that such initiatives are notoriously difficult to establish and maintain (Priestland and Hanig, 2005). Though the importance of leadership development is widely acknowledged (Day, 2000), Tichy and Cohen (1997) point out that it must be supported if it is not to remain a 'haphazard process' (Conger, 1993: 46).

This section will not attempt to provide an exhaustive overview of the broad and hotly debated topic of leadership development, but will limit itself to several potentially significant aspects and concepts. These include an especially topical call for more participatory and reflective approaches (Currie and Knights, 2003; Hill, 2004) - a call that has also been made in the literature on management development, which, though it has diverged from the literature on leadership development, overlaps with it at some points (Day, 2000) - and the importance of on-the-job training and individualized training programmes, which can be particularly useful in developing a capacity for balance.

Classroom programmes can still be an effective route, provided that they make use of the participants' experience and encourage them to reflect (Currie and Knights, 2003; Mintzberg, 2004). However, they do not seem to be enough to develop leadership (Tichy and Cohen, 1997); as Mintzberg (2004: 3) writes, 'no one can create a leader in a classroom', whether the classroom is for the MBA programmes that are so sharply criticized by the author, or for a corporate training course. In addition, these programmes have now been flanked by many other approaches to leadership development; in their systematic review, for instance, Hartley and Hinksman (2003) identify 11 methods, only one of which is 'formal programmes'. Today, one of the central ideas in leadership development is that of helping people learn from their work, rather than taking them away from their work to learn (Moxley and O'Connor Wilson, 1998), in the conviction that 'some of the most powerful leadership learning occurs on the job' (Simkins, 2009: 394).

Work-based learning can take many forms. Woodall and Winstanley (1998), for example, identify three categories: learning from another person (including - among the practices mentioned by Day, 2000 - mentoring and coaching), learning from tasks (e.g. job assignments) and learning with others (e.g. networks and action learning). The following pages will concentrate on the first of these categories, because individualized, one-to-one training (see Boldizzoni and Nacamulli, 2004) appears better able to meet the needs of generative, balanced leadership, and is closer to a relational leadership model (Higgs, 2009). In addition to being participatory and reflective, these methods put the relationship at the centre: something that - for McCauley and Guthrie (2007), authors associated with the Center for Creative Leadership which has published a major Handbook of Leadership Development (McCauley et al., 1998) - is only natural in creating leader development programmes. The relationship provides a vantage point from which the shadows, the dark sides (including those of leadership, which according to Clements and Washbush (1999) should be identified and borne in mind during training) are more readily seen and pondered, the medium whereby generative capacity can be tried out, exercised and reflected on.

Several types of developmental relationship can play an important role for leadership training (Lankau and Scandura, 2007), including mentoring, coaching, counselling and tutoring. Greater attention, however, will be devoted to the first two options, in the conviction that the difference between these relations is more a question of taxonomy than 
of substance (Walker, 2004). In addition, analysing all of the different practices would not only complicate the picture, it would also be a duplication of effort, as there are a number of overlapping areas that fall in certain respects outside the scope of this article. Finally, both mentoring and coaching are often mentioned as effective tools for leadership training (Griffin, 2003), leadership development (Day, 2000) and succession planning (Redman, 2006), and have also been used successfully in combination as part of leader development programmes (McCauley and Guthrie, 2007). Nevertheless, it is recognized that further work is still needed in order to assess the processes and outcomes of mentoring (Solansky, 2010) and coaching (Ely et al., 2010) as leadership development tools.

If these relationships are often regarded as particularly suitable for supporting leadership development, the psychodynamic approach warns of the risks of both mentoring (Baum, 1992) and coaching (Kets de Vries, 2006), which to proceed successfully call for empathy (cited for mentoring by Fletcher and Ragins, 2007, for example, as well as for coaching, for example by Kets de Vries, 2006), commitment and motivation to build the relationship (Kets de Vries, 2006; Kilburg, 2001). In connection with the critical aspect of leadership discussed in this paper, it is thus important to point out that mentoring and coaching are not advisable in cases where the leader's narcissistic traits are very prominent or are more reactive than constructive. This is true for mentoring, as indicated by Maccoby (2000), as well as for coaching, which 'rarely goes well with clients who have complex psychological problems' (Kets de Vries, 2006: 267). We could thus say that mentoring and coaching appear to require an adeptness with relationships, what Chandler (2006; see Kram and Ragins, 2007) calls 'relational savvy'.

Mentoring - as its application in supporting new hires' organizational socialization (Chao, 2007) leads us to think - seems to be more useful as a method for helping fledgling entrepreneurs along the road to leadership, promoting generativity by involving them in relationships with senior entrepreneurs, possibly from other firms.

Of the two developmental relationships considered here, coaching is by contrast more suitable for supporting senior entrepreneurs/leaders - though it is not without its downsides in succession processes. This is possible where the coach is trained to manage complex relationships (Kets de Vries, 2004) and for a set of reasons that will be returned to later.

Organizational mentoring - a relationship between a young adult and an older, more experienced adult who supports, guides and counsels the younger individual to navigate in the adult world and the world of work (Kram, 1985) - can take place in two ways, informal or formal, or in other words as a relationship that arises spontaneously out of mutual interest, or from a programme initiated by the organization to establish mentor/protégé pairs (Allen et al., 2005; Eby and Lockwood, 2005).

In its informal guise, this practice is mentioned for its importance in leadership training by Walker (2002), who states that, in the absence of comprehensive training, the rookie manager's boss plays a crucial role, an idea that has been echoed by Tichy and Cohen (1997: 12), who emphasize the organization's need for leaders, and top leaders in particular, who are 'personally committed to developing other leaders'. Supervisory mentoring relationships can fulfil a significant function in leadership development, for instance by bolstering the psychological safety needed for change (Lankau and Scandura, 2007). Nor is the informal mentoring provided by a supervisor or senior colleague seen as the only potential tool for leadership development: formal mentoring (Baugh and Fagenson-Eland, 2007) and the more recent variations of the relationship such as peer mentoring and group mentoring (McManus and Russell, 2007) have also attracted attention in this regard. 
It would appear that organizational mentoring can play a fundamental role in leadership acquisition and development for many reasons. First, it provides an on-the-job learning relationship. Recent studies have offered evidence that trainees see these forms of learning as the most effective of all methods considered (see Sung and Quinn, 2006). In addition, working interactions facilitate on-the-job transfer of learning (Kitching, 2008). While transfer is a pressing concern in current training practice and research (Blume et al., 2010; Liebermann and Hoffmann, 2008), it is no less of an issue for leadership training (GilpinJackson and Bushe, 2007). Once again, mentoring, when internal (Baugh and FagensonEland, 2005), can aid in the socialization of that specific and localized 'embedded knowledge' (Badaracco, 1991) which cannot be separated from the context producing it (Lave and Wenger, 1991). Further reasons for assigning mentoring a particularly important role among leadership training methods spring from distinctive characteristics of this relationship. First, its historical origin (mentoring takes its name from Mentor in Homer's Odyssey) brings mentoring closer to the educational aspect of training (Quaglino, 2005). Educationoriented training - as distinct from if not actually opposed to instruction-oriented training aims to build routes to individual growth and development that go beyond merely acquiring knowledge and skills (Quaglino, 2005). Second, mentoring's mutuality (Allen and Eby, 2003; Kram, 1985) and the resulting potential for 'intersecting exercise' of leadership, both by protégé who are learning to lead, and by mentors in their teaching capacity. Over time, this reciprocity can lead to true learning partnerships (McCauley and Guthrie, 2007). Finally, mentoring's potential characteristics include depth and intensity (Kram, 1985), as well as generativity (Fletcher and Ragins, 2007). Indeed, generativity is numbered among the five categories of expected benefits for mentors identified by Ragins and Scandura (1999), who define it as the capacity for leaving a legacy to future generations. This characteristic has become even more important for the recent view of mentoring which, unlike the traditional perspective, regards it as relational, and capable of including interdependent processes that result in a full range of relational outcomes for both mentors and protégés (Fletcher and Ragins, 2007). Relational mentoring, in fact, is defined as 'an interdependent and generative [our emphasis] developmental relationship that promotes mutual growth, learning and development within the career context' (Ragins, 2005: 10, see Fletcher and Ragins, 2007: 374). This new perspective on mentoring could further enhance its value as a training tool for instilling generative leadership and a type of leadership that can create a culture of generativity in the organization. Using mentoring to develop leadership would thus appear to be strategic, inasmuch as it is both a concrete support for the protégé and an example, given its widely recognized role modelling function (Kram, 1985), of 'generativity in action', of sharing and generosity.

As is the case for leadership, no review of mentoring would be 'balanced' if it did not mention the potential disadvantages and difficulties of the relationship, both for the protégé (Simon and Eby, 2003) and for the mentor (Eby et al., 2008) as well as, from a psychodynamic standpoint, the 'shadows' (Baum, 1992; Quaglino, 2004) that mentoring brings with it. Where mentors feel jealousy, anger, resentment or envy of the protégés (Baum, 1992), they may engage in tyranny, sabotage or intentional exclusion (Simon and Eby, 2003), to mention only a few of the types of conduct discussed in the literature. For this reason, and because of the self-enhancement motive that can contribute to willingness to mentor (Allen, 2003), it is important to select the mentors involved in formal programmes with care (Ghislieri et al., 2009), especially if their tasks will entail providing support for leadership (Godshalk and Sosik, 2007) and leaders' generative capacities in particular. 
As for coaching, the type of interest here is executive coaching, a facilitative one-to-one, mutually designed relationship that 'is usually focused on organizational performance or development, but may also have a personal component as well' (Kampa-Kokesch and Anderson, 2001: 209). This component, it could be assumed, increases in prominence to the extent that executive coaching emphasizes the dynamic and constantly evolving aspect of the relationship (Ely et al., 2010), and is viewed and 'exercised' from a psychodynamic perspective (Kets de Vries, 2005; Kets de Vries et al., 2007; Kets de Vries et al., 2010; Kilburg, 2004) or using a 'systems-psychodynamic' approach such as that taken by the authors, all ISPSO members, who contributed to the recent volume edited by Halina Brunning (2006).

Regardless of the perspective taken, in any case, the 'essential' idea is to put the client at the centre of the learning process, in a position 'of power', but not forgetting to focus on the interaction between the individual's specific characteristics and abilities and the characteristics of the work setting, an interaction that is all the more important if coaching is intended as a means of training for leadership (Winum, 2005).

In this latter context, coaching has attracted increasing attention (Brunning, 2006; Ely et al., 2010; Griffin, 2003; Kampa-Kokesch and Anderson, 2001; Kets de Vries et al., 2007; Walker, 2002; Winum, 2005), and has indeed been singled out as the approach of choice in management and leadership development (Brunning, 2006). This close liaison can be explained to some extent by coaching's objective of 'being trained to train' (Fatali et al., 2002) and to some extent by the fact that it is an inherently reflective activity (Jackson, 2004) whose aim is a 'reflecting reviewing' (Dubouloy, 2004) of events which can create more reflective people (Kets de Vries et al., 2010). Because of this potential, coaching can thus meet the need for participation and reflection in training (Currie and Knights, 2003), and can also promote balance in leadership, providing that the coaching relationship is marked by mutual security (Ely et al., 2010). Several authors maintain that particular levels of depth can be reached through coaching - partly because it is provided by a trained professional, who should be able to establish a relationship with the coachee which is less affected by personal interests and the organizational culture than that involved in mentoring (Kets de Vries, 2004). This relationship could make it possible to come to grips - though with great caution and a number of attendant risks - with leaders' narcissism (Kearney, 2010) or other shadow aspects (Kilburg, 2004). For this reason, it is essential on the one hand that the coach have an appropriate psychological background, has been exposed to the basics of dynamic psychotherapy, and is attuned to the unconscious life of organizations and, on the other hand, that organizations take great care in choosing coaches (Kets de Vries, 2004, 2005).

\section{Conclusion}

This paper has explored the ability to manage a succession as both an elemental characteristic of leadership and one of its problematic aspects. Generative leadership which can groom new leaders entails an orientation towards sharing and balanced participation in relationships with followers.

Achieving a succession, however, is often problematic (Le Breton-Miller et al., 2004; Redman, 2006), as witnessed by the difficulty encountered in business transfers: a difficulty that, as certain data have shown, is particularly critical in Italy (Delai, 2009). While the reasons for this difficulty can be traced to cultural factors, another pathway for gaining insight into this issue - a pathway which complements rather than contrasts with the 
cultural perspective, and, it is hoped, will be combined with it in future work - is that of 'bad leadership'. Specifically, this paper has drawn on the psychodynamic approach (as taken by Manfred Kets de Vries in particular) to narcissism and loss of power.

This approach can be used to reflect on leadership failure, linking it to the inability to achieve a succession, to generate new leadership: a problem which is not limited to explicitly destructive leadership, but is also associated with that brand of leadership that fascinates and involves its followers (but which carries a whiff of narcissism with it) that can bring shortterm success but is more oriented towards satisfying personal needs (for visibility, positive presentation, approval) than towards building a future for others and for the organization.

By contrast, generative leadership means being willing to share power, recognizing that nobody is irreplaceable; it means putting illusions of perfection to the test in order to build relationships based on being able to share openly, accept and talk about assessment, manage conflicts; it means looking to the future with justifiable confidence.

This balanced leadership, so rarely found, is not likely to arise from strictly traditional classroom training methods. A more appropriate alternative would appear to be individualized, one-to-one training techniques, which can provide multiple occasions for participation, reflection and active trial; above all, they put the relationship at centre stage. Specifically, as these pages have shown, these techniques (mentoring, in particular) can initiate a relationship which is in itself an example of generativity in action and, in the case of coaching, provide an opportunity for self-reflection that helps the coachee move in the direction of balance. Both mentoring and coaching would thus appear to have enormous potential for developing balanced leadership, though the problems that can arise must be considered and monitored. The possible determinants of these problems include personality characteristics that can exert an influence on the relationship. Among these characteristics, according to Maccoby (2000: 73), narcissism plays a prominent role: it is 'difficult for narcissists to mentor and be mentored'. This is confirmed by a recent study by Allen and colleagues (2009), which demonstrates that protégés with greater narcissistic entitlement report relationships of lower quality and shorter duration than do protégés with lesser narcissistic entitlement. If narcissism is thus a point to be watched when selecting new leaders for training, it is a hurdle that is hard to clear when attempting to involve leaders in the succession process, especially if the relationship is to be a lasting one (McWilliams, 1994).

Here, there are no clear and unambiguous solutions; rather, the only thing that is certain is the need to promote positive successions. However, insights can be sought in the clinical knowledge and therapeutic implications associated with treating narcissism, as regards the importance of patience and of dealing with countertransfer (McWilliams, 1994). This is an area that can provide valuable suggestions for the consultant following a formal mentoring programme, for the coach assigned to a leader with narcissist traits who must navigate through a succession, for the aspirant leader. The goal is not to 'treat the narcissistic leader' (the setting is markedly different), but to understand and recognize certain characteristics in order to try to work towards promoting greater generativity.

Theoretical thinking about leadership and the practices supporting succession could thus benefit significantly from a greater influx of clinical knowledge, and its theoretical repercussions and implications for practice, though it must be recognized that this knowledge cannot be transferred from one context to another without careful adaptation followed by the necessary verification. 
The reflective route followed here is based on theoretical work, research and consulting practices developed and implemented in countries other than Italy. In Italy, psychological research in organizational leadership should address a number of areas through qualitative and quantitative studies in the near future, for example by:

- Exploring the dynamics that emerge in managing succession - and not just in the highest positions and at the helm of family-owned businesses - identifying common factors and specific aspects;

- Gaining an understanding of the role played by followers (especially as regards tendencies towards collusion) in terms of motivations and actions in problematic succession situations;

- Verifying the effectiveness of individualized training methods in developing leadership, with particular attention to identifying the strong points and weaknesses of mentoring and coaching techniques.

Addressing these questions could not only enrich the knowledge of leadership, but could also - and above all - provide tools for curbing the dangers of bad leadership.

\section{Acknowledgements}

The authors would like to thank Professor Gian Piero Quaglino for his helpful comments and Scott Kraemer for translating the article.

\section{References}

Aasland MS, Skogstad A, Notelaers G, Nielsen BM and Einarsen S (2010) The prevalence of destructive leadership behavior. British Journal of Management 21(2): 438-452.

Alimo-Metcalfe B (1995) An investigation of female and male constructs of leadership and empowerment. Women in Management Reviews 10(2): 3-8.

Allcorn S and Diamond M (1997) Managing During Stressful Times: The Psychologically Defensive Workplace. Westport: Quorum.

Allen TD (2003) Mentoring others: A dispositional and motivational approach. Journal of Vocational Behavior 62(1): 134-154.

Allen TD and Eby LT (2003) Relationships effectiveness for mentors: Factors associated with learning and quality. Journal of Management 29(4): 469-486.

Allen TD, Day R and Lentz E (2005) The role of interpersonal comfort in mentoring relationships. Journal of Career Development 31(3): 155-169.

Allen TD, Johnson HM, Xu X, Biga A, Rodopman OB and Ottinot RC (2009) Mentoring and protégé narcissistic entitlement. Journal of Career Development 35(4): 385-405.

Ancona D, Malone TW, Orlikowski WJ and Senge PM (2007) In praise of the incomplete leader. Harvard Business Review 85(2): 92-100.

Åteg M, Wilhelmson L, Backström T, Moström Åberg M, Köping Olsson B and Önnered L (2009). Tasks in the generative leadership: Creating conditions for autonomy and integration. Available at: www.du.se/PageFiles/8823/Microsoft\%20Word\%20-\%20RWL6_-_Tasks_in_the_ generative_leadership.pdf (accessed 20 August 2011).

Avolio BJ and Gardner TW (2005) Authentic leadership development: Getting to the root of positive forms of leadership. The Leadership Quarterly 16(3): 315-338.

Badaracco J (1991) The Knowledge Link: How Firms Compete through Strategic Alliances. Boston: Harvard Business Press. 
Baugh SG and Fagenson-Eland EA (2005) Boundaryless mentoring: An exploratory study of the functions provided by internal versus external organizational mentors. Journal of Applied Social Psychology 35(5): 939-955.

Baugh SG and Fagenson-Eland EA (2007) Formal mentoring programs: A 'poor cousin' to informal relationships? In: Ragins BR and Kram KE (eds) The Handbook of Mentoring at Work Theory, Research, and Practice. Thousand Oaks, CA: Sage, 249-271.

Baum HS (1992) Mentoring: Narcissistic fantasies and oedipal realities. Human Relations 45(3): 223-245.

Benson MJ and Hogan RS (2008) How dark side leadership personality destroys trust and degrades organizational effectiveness. Organization and People 15(3): 10-18.

Blume BD, Ford JK, Baldwin TT and Huang JL (2010) Transfer of training: A meta-analytic review. Journal of Management 36(4): 1065-1105.

Boldizzoni D and Nacamulli RCD (2004) Oltre l'aula. Strategie di formazione nell'economia della conoscenza [Beyond the Classroom. Training Strategies in the Knowledge Economy]. Milano: Apogeo.

Brunning H (2006) Executive Coaching: Systems Psychodynamic Perspective. London: Karnac Books. Burns JM (1978) Leadership. New York: Harper Collins.

Carboni C, Castronovo V, Delai N, Egidi M, Marturano A, Oriani R and Quaglino GP (2009) Crescere al futuro. Leadership e continuità d'impresa oltre la crisi [Growing into the Future. Leadership and Business Continuity beyond the Crisis]. Milano: Il Sole 24 Ore.

Chao GT (2007) Mentoring and organizational socialization: Networks for work adjustment. In: Ragins BR and Kram KE (eds) The Handbook of Mentoring at Work. Theory, Research, and Practice. Thousand Oaks, CA: Sage, 179-196.

Chatterjee A and Hambrick DC (2007) It's all about me: Narcissistic chief executives and their effects on company strategy and performance. Administrative Science Quarterly 52(3): 351-386.

Clements C and Washbush JB (1999) The two faces of leadership: Considering the dark side of leaderfollower dynamics. Journal of Workplace Learning 11(5): 170-176.

Cogliser CC and Brigham KH (2004) The intersection of leadership and entrepreneurship: Mutual lessons to be learned. The Leadership Quarterly 15(6): 771-799.

Conger JA (1990) The dark side of leadership. Organizational Dynamics 19(2): 44-55.

Conger JA (1993) The brave new world of leadership training. Organizational Dynamics 21(3): 46-58.

Cucculelli M and Micucci G (2008) Family succession and firm performance: Evidence from Italian family firms. Journal of Corporate Finance 14(1): 17-31.

Currie G and Knights D (2003) Reflecting on a critical pedagogy in MBA education. Management Learning 34(1): 27-49.

Daft RL and Lengel RH (1998) Fusion Leadership: Unlocking the Subtle Forces That Change People and Organizations. San Francisco, CA: Berrett-Koehler.

Day DV (2000) Leadership development: A review in context. The Leadership Quarterly 11(4): 581-613.

Delai N (2009) L'emergere della leadership nei processi di continuità aziendale [The emergence of leadership in processes of business continuity]. In: Carboni C, Castronovo V, Delai N, Egidi M, Marturano A, Oriani R and Quaglino GP (eds) Crescere al futuro. Leadership e continuità d'impresa oltre la crisi [Growing into the Future. Leadership and Business Continuity beyond the Crisis]. Milano: Il Sole 24 Ore, 43-66.

Dorfman P (2004) International and cross-cultural leadership. In: Punnett BJ and Shenkar O (eds) Handbook for International Management Research. Ann Arbor, MI: The University of Michigan Press, 265-335.

Dubouloy M (2004) The transitional space and self-recovery: A psychoanalytical approach to highpotential managers' training. Human Relations 57(4): 467-496.

Eby LT and Lockwood A (2005) Protégés' and mentors' reactions to participating in formal mentoring programs: A qualitative investigation. Journal of Vocational Behavior 67(3): 441-458. 
Ely K, Boyce LA, Nelson JK, Zaccaro SJ, Hernez-Broome G and Whyman W (2010) Evaluating leadership coaching: A review and integrated framework. The Leadership Quarterly 21(4): $585-599$.

Eby LT, Durley JR, Evans SC and Ragins BR (2008) Mentors' perceptions of negative mentoring experiences: Scale development and nomological validation. Journal of Applied Psychology 93(2): $358-373$.

Erikson EH (1968) Identity: Youth and Crisis. New York: Norton.

European Commission. (1994) Commission Recommendation of 7 December 1994 on the transfer of small and medium-sized enterprises. Available at: http://eur-lex.europa.eu/LexUriServ/ LexUriServ.do?uri=CELEX:31994H1069:en:HTML (accessed 20 August 2011).

European Commission. (2006a) Markets for business transfers. Fostering transparent marketplaces for the transfer of businesses in Europe. Report of the Expert Group. Available at: http://ec.europa.eu/ enterprise/policies/sme/files/support_measures/transfer_business/transfer_markets_en.pdf (accessed 20 August 2011).

European Commission. (2006b) Transfer of businesses: Continuity through a new beginning. Available at: http://europa.eu/legislation_summaries/enterprise/business_environment/ 110111_it.htm (accessed 20 August 2011).

European Commission. (2009) A helping hand for SMEs: Mentoring business transfer. Available at: http://ec.europa.eu/enterprise/policies/sme/files/support_measures/transfer_business/ mentoring_business_transfer_en.pdf (accessed 20 August 2011).

Fatali G, Nardini G and Sprega F (2002) Il coaching organizzativo. Come allenare le risorse umane all'apprendimento, al cambiamento ed all'innovazione [Organizational Coaching. How to Train Human Resources for Learning, Changing and Innovating]. Milano: Franco Angeli.

Fletcher JK and Ragins RB (2007) Stone Center relational cultural theory: A window on relational mentoring. In: Ragins BR and Kram KE (eds) The Handbook of Mentoring at Work. Theory, Research, and Practice. Thousand Oaks, CA: Sage, 373-399.

Frost P (2004) Handling toxic emotions: New challenges for leaders and their organization. Organizational Dynamics 33(2): 111-127.

Frost P and Robinson S (1999) The toxic handler: Organizational hero and casualty. Harvard Business Review 77(4): 96-106.

Gambel EL (2004) Il ricambio generazionale nell'impresa familiare italiana. Un metodo per valutare e preparare gli eredi alla successione aziendale [Generational Change in Italian Family Businesses. A Method for Evaluating and Preparing Heirs for Succession]. Milano: Franco Angeli.

Ghislieri C, Gatti P and Quaglino GP (2009) Factors affecting willingness to mentor. International Journal for Educational and Vocational Guidance 9(3): 205-219.

Gilpin-Jackson Y and Bushe GR (2007) Leadership development training transfer: A case study of post-training determinants. Journal of Management Development 26(10): 980-100.

Godshalk VM and Sosik JJ (2007) Mentoring and leadership: Standing at the crossroads of theory, research, and practice. In: Ragins BR and Kram KE (eds) The Handbook of Mentoring at Work. Theory, Research, and Practice. Thousand Oaks, CA: Sage, 149-178.

Griffin NS (2003) Personalize your management development. Harvard Business Review 81(3): 113-119.

Hartley J and Hinksman B (2003) Leadership Development: A Systematic Review of the Literature. Warwick: Warwick Business School.

Higgs M (2003) How we can make sense of leadership in the 21st century? Leadership and Organization Development Journal 24(5): 273-284.

Higgs M (2009) The good, the bad and the ugly: Leadership and narcissism. Journal of Change Management 9(2): 165-178.

Hill LA (2004) New manager development for the 21st century. The Academy of Management Executive 18(3): 121-126.

Hill LA (2007) Becoming the boss. Harvard Business Review 85(1): 48-56. 
Hirschhorn H (1998) The psychology of vision. In: Klein EB, Gabelnick F and Herr P (eds) The Psychodynamics of Leadership. Madison, WI: Psychosocial Press, 109-126.

Hogan R, Curphy GJ and Hogan J (1994) What we know about leadership: Effectiveness and personality. American Psychologist 49(3): 493-504.

House RJ, Hanges PJ, Javidan M, Dorfman PW and Gupta V (eds) (2004) Culture, Leadership and Organizations: The GLOBE Study of 62 Societies. Thousand Oaks, CA: Sage.

Jackson P (2004) Understanding the experience of experience: A practical model of reflective practice for coaching. International Journal of Evidence Based Coaching and Mentoring 2(1): 57-67.

Kampa-Kokesch S and Anderson MZ (2001) Executive coaching: A comprehensive review of the literature. Consulting Psychology Journal: Practice and Research 53(4): 205-228.

Kearney KS (2010) Grappling with the gods: Reflections for coaches of the narcissistic leader. International Journal of Evidence Based Coaching and Mentoring 8(1): 1-13.

Keats J (1984) Lettere sulla poesia [Letters on Poetry]. (Nadia Fusini, Trans.). Milano: Feltrinelli.

Kellerman B (2007) What every leader needs to know about followers. Harvard Business Review 85(12): 84-91.

Kets de Vries MFR (1980) Organizational Paradoxes. London: Tavistock.

Kets de Vries MFR (1993) Leaders, Fools, and Impostors: Essays on the Psychology of Leadership. San Francisco, CA: Jossey-Bass.

Kets de Vries MFR (1995) Life and Death in the Executive Fast Lane: Essays on Irrational Organizations and Their Leaders. San Francisco, CA: Jossey-Bass.

Kets de Vries MFR (2001) Struggling with the Demon: Essays on Individual and Organizational Irrationality. Madison, Wi: Psychosocial Press.

Kets de Vries MFR (2004) Coach or Couch, Anybody? The Zen of Creating High-EQ Organizations. Available at: www.orgdyne.com/coaching/online\%20bib/CoachorCouch_01.pdf (accessed 20 January 2011).

Kets de Vries MFR (2005) Leadership group coaching in action: The Zen of creating high performance teams. Academy of Management 19(1): 61-76.

Kets de Vries MFR (2006) The Leader on the Couch: A Clinical Approach to Changing People and Organizations. San Francisco, CA: Jossey Bass.

Kets de Vries MFR (2007) The eight roles executives play. Organizational Dynamics 36(1): 28-44.

Kets de Vries MFR and Miller D (1997) Narcissism and leadership: An object relations perspective. Human Relations 38(4): 583-601.

Kets de Vries MFR, Guillen Ramo L, Korotov K and Florent-Treacy E (2010) The Coaching Kaleidoscope: Insights from the Inside. New York: Palgrave Macmillan.

Kets de Vries MFR, Korotov K and Florent-Treacy E (2007) Coach and Couch: The Psychology of Making Better Leaders. New York: Palgrave Macmillan.

Khoo HS and Burch GSJ (2008) The 'dark side' of leadership personality and transformational leadership: An exploratory study. Personality and Individual Differences 44(1): 86-97.

Kilburg RR (2001) Facilitating intervention adherence in executive coaching. A model and methods. Consulting Psychology Journal: Practice and Research 53(4): 251-267.

Kilburg RR (2004) When shadows fall: Using psychodynamic approaches in executive coaching. Consulting Psychology Journal: Practice and Research 56(4): 246-268.

Kitching J (2008) Rethinking UK small employers' skills policies and the role of workplace learning. International Journal of Training and Development 12(2): 100-120.

Kram KE (1985) Mentoring at Work. Glenview, IL: Scott Foresman.

Kram KE and Ragins BR (2007) The landscape of mentoring in the 21st century. In: Ragins BR and Kram KE (eds) The Handbook of Mentoring at Work. Theory, Research, and Practice. Thousand Oaks, CA: Sage, 659-692.

Lankau MJ and Scandura TA (2007) Mentoring as a forum for personal learning in organizations. In: Ragins BR and Kram KE (eds) The Handbook of Mentoring at Work. Theory, Research, and Practice. Thousand Oaks, CA: Sage, 95-122. 
Lave J and Wenger E (1991) Situated Learning: Legitimate Peripheral Participation. Cambridge: University of Cambridge Press.

Le Breton-Miller I, Miller D and Steier LP (2004) Toward an integrative model of effective FOB succession. Entrepreneurship: Theory and Practice 28(4): 305-328.

Liebermann S and Hoffmann S (2008) The impact of practical relevance on training transfer: Evidence from a service quality training program for German bank clerks. International Journal of Training and Development 12(2): 74-86.

Lipman-Blumen J (2005) The Allure of Toxic Leaders. Why we Follow Destructive Bosses and Corrupt Politicians. Oxford: Oxford University Press.

Maccoby M (2000) Narcissistic leaders: The incredible pros, the incredible cons. Harvard Business Review 78(1): 68-79.

Marturano A (2009) La percezione della leadership nei diversi contesti culturali [The perception of leadership in different cultural contexts]. In: Carboni C, Castronovo V, Delai N, Egidi M, Marturano A, Oriani R and Quaglino GP (eds) Crescere al futuro. Leadership e continuità d'impresa oltre la crisi [Growing into the Future. Leadership and Business Continuity beyond the Crisis]. Milano: Il Sole 24 Ore, 89-106.

McCall M and Lombardo M (1983) Off the Track: Why and How Successful Executives get Derailed. Greensboro, NC: Center for Creative Leadership.

McCauley CD and Guthrie VA (2007) Designing relationships for learning into leader development programs. In: Ragins BR and Kram KE (eds) The Handbook of Mentoring at Work. Theory, Research, and Practice. Thousand Oaks, CA: Sage, 573-591.

McCauley CD, Moxley RS and Van Velsor E (eds) (1998) The Center for Creative Leadership Handbook of Leadership Development. San Francisco, CA: Jossey-Bass.

McGill ME and Slocum JR (1998) A little leadership, please? Organizational Dynamics 26(3): 39-48.

McManus SE and Russell JEA (2007) Peer mentoring relationships. In: Ragins BR and Kram KE (eds) The Handbook of Mentoring at Work. Theory, Research, and Practice. Thousand Oaks, CA: Sage, 273-297.

McWilliams N (1994) Psychoanalytic Diagnosis. Understanding Personality Structure in the Clinical Process. New York: The Guilford Press.

Mintzberg H (2004) Managers not MBAs: A Hard Look at the Soft Practice of Managing and Management Development. San Francisco, CA: Berrett-Koehler Publishers.

Moxley RS and O'Connor Wilson P (1998) A systems approach to leadership development. In: McCauley CD, Moxley RS and Van Velsor E (eds) The Center for Creative Leadership Handbook of Leadership Development. San Francisco, CA: Jossey-Bass, 217-241.

Northouse PG (2010) Culture and leadership. In: Northouse PG (ed.) Leadership. Theory and Practice (Fifth edition). Thousand Oaks, CA: Sage, 335-376.

Pardo-del-Val M (2009) Succession in family firms from a multistaged perspective. International Entrepreneurship and Management Journal 5(2): 165-179.

Passeri R (2007) Valutazioni imprenditoriali per la successione nell'impresa familiare [Entrepreneurial Evaluations for Succession in the Family Business]. Firenze: Firenze University Press.

Priestland A and Hanig R (2005) Developing first-level leaders. Harvard Business Review 83(6): $112-120$.

Quaglino GP (2004) La vita organizzativa [The Organizational Life]. Milano: Raffaello Cortina.

Quaglino GP (2005) Fare formazione. I fondamenti della formazione e $i$ nuovi traguardi [Providing Training. The Basics of Training and the New Goals]. Milano: Raffaello Cortina.

Quaglino GP (2009) Il valore della parola leadership [The value of the word leadership]. In: Carboni C, Castronovo V, Delai N, Egidi M, Marturano A, Oriani R and Quaglino GP (eds) Crescere al futuro. Leadership e continuità d'impresa oltre la crisi [Growing into the Future. Leadership and Business Continuity beyond the Crisis]. Milano: Il Sole 24 Ore, 3-30.

Ragins BR and Scandura TA (1999) Burden or blessing? Expected costs and benefits of being a mentor. Journal of Organizational Behavior 20(4): 493-509. 
Rapporto Luiss (2008) Generare classe dirigente. Una sintonia positiva da ritrovare con il paese [Generating a Managerial Class. Getting Back in Tune with the Country]. Milano: Il Sole 24 Ore.

Redman RW (2006) Leadership succession planning. An evidence-based approach for managing the future. The Journal of Nursing Administration 36(6): 292-297.

Resick CJ, Withman DS, Weingarden SM and Hiller NJ (2009) The bright-side and the dark-side of CEO personality: Examining core self-evaluations, narcissism, transformational leadership, and strategic influence. Journal of Applied Psychology 94(6): 1365-1381.

Rosenthal SA and Pittinsky TL (2006) Narcissistic leadership. Leadership Quarterly 17(6): 617-633.

Simkins T (2009) Integrating work-based learning into large-scale national leadership development programmes in the UK. Educational Review 61(4): 391-405.

Simon SA and Eby LT (2003) A typology of negative mentoring experiences: A multidimensional scaling study. Human Relations 56(9): 1083-1106.

Simpson P, French R and Harvey CE (2002) Leadership and negative capability. Human Relations 55(10): 1209-1226.

Solansky ST (2010) The evaluation of two key leadership development program components: Leadership skills assessment and leadership mentoring. The Leadership Quarterly 21(4): 675-681.

Stech EL (2010) Psychodynamic approach. In: Northouse PG (ed.) Leadership. Theory and Practice (5th edn). Thousand Oaks, CA: Sage, 271-300.

Sung J and Quinn M (2006) Learning and Development: Annual Survey Report 2006 (London: CIPD). Available at: http://www.cipd.co.uk/NR/rdonlyres/97BE272C-8859-4DB1-BD99-17F38E4B4484/ 0/lrnandevsurv0406.pdf (accessed 20 August 2011).

Surie G and Hazy J (2006) Generative leadership: Nurturing innovation in complex systems. Emergence: Complexity \& Organization 8(4): 13-26.

Tichy NM and Cohen E (1997) The Leadership Engine: How Winning Companies Build Leaders at Every Level. New York: Harper Business.

Vecchio RP (2003) Entrepreneurship and leadership: Common trends and common threads. Human Resource Management Review 13(2): 303-327.

Walker CA (2002) Saving your rookie managers from themselves. Harvard Business Review 80(4): 97-102.

Walker S (2004) The evolution of coaching: Patterns, icons and freedom. International Journal of Evidence Based Coaching and Mentoring 2(2): 16-28.

Winum PC (2005) Effectiveness of a high-potential African American executive: The anatomy of a coaching engagement. Consulting Psychology Journal: Practice and Research 57(1): 71-89.

Woodall J and Winstanley D (1998) Management Development: Strategy and Practice. London: Blackwell.

Chiara Ghislieri is Associate Professor of Work and Organizational Psychology (Università di Torino Department of Psychology). Her research interests include work-family balance and conflict, well-being in organizations, leadership and vocational guidance.

Paola Gatti is a postdoctoral fellow at the Università di Torino Department of Psychology. Her research interests include mentoring in organizations, leadership and vocational guidance. 